\title{
BERTEOLOGI DALAM KONTEKS INDONESIA MODERN
}

\author{
Desti Samarenna \\ Sekolah Tinggi Teologi International Harvest Semarang \\ Rukan Mutiara Marina No.40, Semarang - Jawa Tengah \\ Email: destisamarenna@gmail.com
}

\begin{abstract}
Desti Samarenna, Having theology in Modern Indonesia Context. This paper wants to show how to do theology in the context of modern Indonesia where the true understanding of Christ and his work as true God and true man bring proper hermeneutics of the theological positions of religion, culture, modernization, philosophy, and ethics so this criticism is a preparatory step towards reflection theological. Then, it provides responses from the standpoint of the Bible how the position as believers that is in a plural nation.
\end{abstract}

Keyword: Theology, Hermeneutics, Christology.

\begin{abstract}
ABSTRAK: Desti Samarenna, Berteologi Dalam Konteks Indonesia Modern. Tulisan ini ingin menunjukkan bagaimana berteologi dalam konteks Indonesia modern dimana dengan pemahaman yang benar tentang Kristus dan karya-Nya sebagai Allah sejati dan manusia sejati memunculkan hermeneutika yang benar tentang posisi teologi agama, budaya, modernisasi, filsafat, dan etika sehingga kritik ini adalah langkah persiapan kearah refleksi teologis. Kemudian, tulisan ini memberikan tanggapan dari sudut pandang Alkitab bagaimana posisi sebagai orang percaya yang ada ditengah bangsa yang majemuk.
\end{abstract}

Kata kunci: Teologi, Hermeneutika, Kristologi.

\section{PENDAHULUAN}

Pemahaman teologi yang benar akan membawa kepada prinsip hidup yang benar dan arah yang benar dalam menjalani kehidupan. Teologi itu sangat penting. Browning mengungkapkan bahwa

Dalam jangka waktu yang cukup lama teologi telah dianggap sebagai ratu-ratu ilmu-ilmu pengetahuan dan teologi sistematika sebagai mahkota sang ratu. Teologia sendiri sebagai il$\mathrm{mu}$ pengetahuan dan mempelajari Tuhan dan karya-karya-Nya sedangkan teologia sistematika merupakan sajian teratur dari hasil penelitian teologi dan juga uraian rasional dari suatu agama yang ditunjang oleh sejumlah subdisiplin termasuk studi naskah-naskah suci, etika, doktrin, sejarah dan peribadahan. ${ }^{1}$

Sebagai gerakan ilmu pengetahuan, teologi Alkitab menghadapi banyak tekanan, membicarakan isu-isu yang sedang hangat dewasa ini, seperti rasionalisme, nilai-nilai agama lain, dan pada wahyu dan sejarah,

${ }^{1}$ W. R. F. Browning, "Teologi," dalam Kamus Alkitab: Panduan Dasar Ke Dalam Kitab-kitab, Tema, Tempat, Tokoh dan Istilah Alkitabiah,pen., Liem Khiem Yang dan Bambang Subandrijo (Jakarta: Gunung Mulia, 2007), 442. keluaran dan perjanjian, eksploitasi terhadap sumber daya alam. ${ }^{2}$ Jadi teologi adalah sesuatu yang hidup dan berkenaan dengan keberadaan sebagai manusia dalam situasi khusus tertentu karenanya harus terkait dengan kepercayaan, ungkapan iman klasik dan bentuk-bentuk kultural. Oleh sebab itu perlu diuraikan secara mendalam bagaimana berteologi dalam konteks Indonesia modern. Melalui artikel ini, penulis memberikan uraian tentang berteologi dalam konteks Indonesia modern. Pemaparan dimulai dengan membahas apa yang menjadi sifat teologi, kemudian menguraikan wacana hermeneutika Kristologi pada masa modern dan menguraikan tentang teologi sebagai kritik.

\section{METODE}

Penelitian ini merupakan penelitian pustaka, dimana penulis melakukan studi pustaka dan analisa terhadap teologi dalam konteks Indonesia pada masa kini. Data dalam penelitian ini bersumber dari beberapa buku teologi dengan memperhatikan kepakaran

${ }^{2}$ Ibid, 443. 
dari para penulis buku tersebut. Beberapa buku yang telah lama terbit tetapi bermanfaat untuk kajian ini, tetap penulis gunakan dengan pertimbangan bahwa belum ada buku yang lebih baru dan kualitasnya lebih baik dari buku tersebut. Beberapa karya teolog yang penulis gunakan adalah karya Charles C. Ryrie, Millard J. Erickson, Henry C. Thiessen. Sementara penulis juga menggunakan beberapa buku teologi dengan latar belakang penulis dari Indonesia atau yang hidup berteologinya di Indonesia.

\section{SIFAT TEOLOGI}

Teologi secara historika atau sejarah, mengkaji bagaimana pada masa lampau, dengan berbagai konteksnya, manusia menerima, menanggapi dan ditanggapi oleh amanat Alkitab

Istilah "teologi" dewasa ini dipakai dalam artian yang luas maupun dalam artian yang sempit. Istilah teologia berasal dari dua kata Yunani, Theos dan logos. Theos berarti "Tuhan" dan Logos berarti "kata", "wejangan", atau "ajaran." Dengan demikian secara sempit teologia dapat didefinisikan sebagai kata, ajaran, wejangan tentang Tuhan. Namun, dalam artian yang luas dan lebih umum, istilah teologi berarti seluruh ajaran Kristen, dan bukan sekadar ajaran tentang Tuhan saja, tetapi semua ajaran yang membahas hubungan yang dipelihara oleh Tuhan dengan alam semesta ini. Dalam artian yang luas ini, teologia dapat didefinisikan sebagai ilmu tentang Tuhan dan hubungan-hubungan-Nya dengan alam semesta. ${ }^{3}$

Teologi tidak berakhir dalam dunia pendidikan saja, juga bukan ilmu teoritis dengan struktur nalar namun dapat menyesuaikan dengan keadaan-keadaan yang terus berubah. Pesan atau isinya tetap, namun bentuk dan modusnya mengalami perubahan dalam kaitannya dengan konteks. Teologi juga adalah bagian dari kebudayaan yang dari padanya ia berupaya mengungkapkan diri dengan konteks atau situasi tersebut.

${ }^{3}$ Henry C. Thiessen, Teologi Sistematika, ed., revisi Vernon D. Doerksen (Malang: Gandum Mas, 2000), 2.
Wacana yang menarik adalah di tengahtengah bangsa yang besar, yang memiliki dasar negara Pancasila dengan berbagai aliran agama seperti Kristen, Katholik, Islam, Hindu, Budha, dan Kepercayaan ada berbagai paham yang di bangun tentang siapa Allah yang di sembah. Akar-akar Pancasila telah mewarnai analisis-analisis nilai yang terdapat dalam agama-agama dan kebudayaan-kebudayaan lain, mulai memikirkan ulang tentang teologi Kristen dalam hubungannya dengan konteks-konteks yang berbeda. Inkarnasi Kristus telah menjadikan diri-Nya sebagai sesama bagi manusia. Pergumulan gereja sebagaimana diungkapkan di atas memang sejalan pergumulan masyarakat. Meskipun umat menyadari perlunya etika alkitabiah guna menghadapi tantangan dari isu-isu Kristologi tersebut.

\section{Kristus dan Karya-Nya}

Kebutuhan manusia akan Allah, dilakukan dengan pencapaian-pencapaian yang seringkali hanya produk dari agama saja. Pemahaman Alkitab tentang Trinitas telah memunculkan polemik yang luar biasa. Salah satu bagian yang disoroti adalah benarkan Yesus adalah Allah? Apakah kelahirannya dari budaya dan peradapan manusia yang merupakan hasil hubungan jasmani manusia? Apakah benar Ia adalah pribadi yang harus disembah? Menanggapi hal tersebut tentunya diperlukan jawaban yang benar di tengah bangsa yang pluralis. Ketidaksigapan dan lemahnya apologetika dalam menyikapi isu-isu tersebut sehingga menjadikan orang percaya di tengah masyarakat menjadi apatis. Itulah sebabnya, penulis bermaksud memberikan imbangan agar tetap memelihara pemahaman dan penghayatan kepada Injil, kemudian memahami makna kata "Allah", dikaitkan dengan Kristus, menjadi pergumulan gereja, bagaimana menghadirkan Injil Allah dalam Kristus Yesus kepada manusia dan memberikan peneguhan bahwa Allah menawarkan pengampunan hanya melalui Yesus Kristus dan harus berjumpa dengan Kristus. Yesus Kristus mati bagi semua orang; supaya semua, meskipun di dalam keadaan memberontak ter- 
hadap Allah tetap ada dalam karya pendamaian Kristus. Oleh karena itu penting penerapan karya Kristus bagi kehidupan seseorang. ${ }^{4}$

Pesan Kristiani yang fundamental adalah inkarnasi Kristus yaitu Allah sejati dan manusia sejati. Menyinggung inkarnasi Kristus, ada dua orang penting dalam sejarah gereja yang tidak dapat diabaikan peranan dan perjuangannya dalam mengargumentasikan pesan ini. Pertama seorang bapak gereja pembela iman di hadapan pihak Yahudi dan kafir bernama Athanasius yang menulis buku De incarnatione (tahun 335-337). Athanasius melaui bukunya itu mengargumentasikan kepantasan, ketetapan dan kewajaran penyaliban Kristus dalam inkarnasinya bagi penyelamatan manusia, karena dunia yang di ciptakan oleh Kristus hanya dapat dipulihkan melalui Dia. ${ }^{5}$ Kedua, lebih dari tahun 750 tahun kemudian seorang bapak Teologia Skolastis gereja Barat bernama Anselmus memberikan argumentasi serupa dari bukunya Cur Deus Homo? (tahun 1090) bahwa inkarnasi sebagai jawaban logis bagi permasalahan dosa manusia dan kebutuhan bagi pemuasan keadilan Allah. ${ }^{6}$ Namun kurang dari 750 tahun kemudian seorang teolog modern-liberal bernama Friedrich Daniel Ernst Schleiermacher melalui bukunya The Chriatian Faith (tahun 1830-1831) menyatakan bahwa Kristus adalah manusia biasa dalam segala hal, namun yang dipilih Allah, tidak wewarisi dosa asal, sehingga sejak lahirnya berhasil mengembangkan kesadaran akan kebergantungannya dengan Allah. ${ }^{7}$

\section{Allah Sejati dan Manusia Sejati}

Sejak zaman para rasul, Alkitab menyaksikan bahwa Rasul Paulus dan Yohanes telah mengha-

\footnotetext{
${ }^{4}$ Millard J. Erickson, Teologi Kristen, vol. 3 (Malang: Gandum Mas, 2004), 69.

${ }^{5}$ Toni Lane, Runtut Pijar, terj. Conny Item Corputy (Jakarta: Gunung Mulia, 1993), 27-29. J. F. Jhonson "Athanasius" dalam Evangelical Dictionary of Theologia, ed., Walter A. Elwell (Grand rapids: Baker Book House, 1984), 95.

${ }^{6}$ Ibid, 89, 91.

${ }^{7}$ Yakub S. Susabda, Teologi Modern I (Jakarta: LRII, 1990), 25.
}

dapi ajaran-ajaran sesat Kristologi seperti Docetisme dan Ebionisme. Docetisme merupakan bagian dari ajaran Gnostik yang menolak kemanusiaan Kristus dengan berpendapat bahwa bila Kristus menderita maka Dia bukan Allah dan bila Kristus adalah Allah maka Dia tidak mungkin menderita. Rasul-rasul telah menolak Docetisme dengan menegaskan dalam surat-surat mereka (Rm. 1:3-4; I Yoh. 4:2; 2 Yoh. 7) bahwa Kristus adalah satu pribadi dalam dua kodrat yaitu Allah sejati sekaligus manusia sejati. ${ }^{8}$ Berlawanan dengan Docetisme adalah Ebionisme, yaitu ajaran dari kelompok bidat Kristen Yahudi yang menolak ke-Allahan Kristus. Ajaran ini menekankan monoteisme, menolak kelahiran dari anak dara dan praeksistensi Kristus, serta memegang teguh hukumhukum Yudaisme. Paulus telah menentang hal tersebut melalui suratnya kepada jemaat Galatia. ${ }^{9}$ Jadi sejak zaman para rasul sanggahan terhadap keallahan dan kemanusiaan Kristus telah bergulir dan para rasul telah menyatakan mereka bersalah. Dengan kata lain, para rasul telah meneguhkan keallahan sekaligus kemanusiaan Kristus.

Inkarnasi Kristus telah memfasilitasi manusia melihat Allah sejati sekaligus manusia sejati. Manusia tidak mungkin melihat Allah namun Kristus adalah penyataan Allah sendiri kepada manusia. Realitas manusia melihat Allah adalah realitas kekekalan. Namun realitas manusia yang sudah jatuh kedalam dosa adalah keberadaan yang fana baik tubuh dan jiwanya. Itulah sebabnya, Kristus mengenakan tabiat manusia, tidak hanya menyangkut tubuh tetapi jiwa manusia sejati. Kekristenan memandang manusia sebagai ciptaan Allah; sebagaimana juga pandangan-pandangan agama-agama wahyu, seperti Yudaisme dan Islam. Yesus telah menyelesaikan semua penebusan dengan kematian-Nya. Yesus ber-

${ }^{8}$ G. L. Borchert, "Docetism," dalam Evangelical Dictionary of Theology, ed. Walter A. Elwell (Grand Rapids: Baker Book House, 1984), 326.

${ }^{9}$ Millard J. Erickson, Christian Theology Vol. 2 (Grand Rapids: Baker Book House, 1984), 694, 713. 
sabda "sudah selesai (Yoh. 19:30)."10 Oleh karena itu posisi setiap orang yang percaya dibenarkan.

\section{WACANA HERMENEUTIKA KRISTOLOGI}

Hermeneutika adalah proses peralihan dari sesuatu yang relatif gelap ke dalam sebentuk ungkapan yang jelas dan terang. Hermeneutika adalah masalah yang rumit dan terselubung, namun tidak dapat dihindari. Wilhelm Dilthey berpendapat bahwa mesti ada sebentuk kualitas dalam sorot mata sang penafsir, sebab sesungguhnya dalam teks ada arus batin manusia yang hanya ditangkap melalui mekanisme Versstehen, yaitu memahami sesuatu sambil terlibat dengan "obyek" pemahaman; semua itu ada langkah-langkah metodologinya yang akan membawa kepada pemahaman makna teks secara utuh.

Penyatuan gereja dengan Kristus menuntut gereja terus berupaya mengenali pribadi Kristus secara lebih utuh. Namun tidak bisa disangkali bahwa pribadi Kristus dikenali penuh misteri dan sulit dipahami. Sehingga tidak sedikit ditemukan dalam sejarah gereja tentang pemahaman Kristologi yang dinyatakan bidat, seperti Docetisme, Ebionisme, AriaNisme, Apolinarianisme, Nestorianisme, Eutychianisme, Monophysitisme, dan Monothelitisme. ${ }^{11}$ Isu teologi menjadi pokok pergumulan adalah Kristologi yaitu Kristus adalah Allah sejati sekaligus manusia sejati. Keberadaan Kristus yang paradoks dan misterius inilah menjadikan pengantara sejati antara Allah dan manusia, juga manusia dan sesamanya. ${ }^{12}$ Berkaitan dengan isu tersebut, Yohanes Calvin melanjutkan pergumulan yang panjang dari pendahulunya, seperti Clemens Alexandrinus, Augustinus, dan Thomas Aquinas, di awal bukunya Institutio, mengungkapkan tentang dua bagian dari keseluruhan hik-

\footnotetext{
${ }^{10}$ Toni Evans, Teologi Allah (Malang: Gandum Mas, 1999), 441.

${ }^{11}$ Robert C. Walton, Chronological and Background Charts of Church History (Grand Rapids: Zondervan, 1986), 16.

${ }^{12}$ Th. Van den End, Enam Belas Dokumen dasar Calvinisme (Jakarta: Gunung Mulia, 2004), 17.
}

mat pengetahuan manusia yang benar dan kokoh, yaitu mengenal Allah sejati sekaligus mengenal diri sendiri - manusia yang telah rusak kesejatiannya karena jatuh dalam dosa. ${ }^{13}$ Oleh sebab itu penting memahami Allah dalam wacana yang benar.

\section{Teologi dan Agama}

Istilah "agama" dipakai dalam berbagai arti yang sangat berbeda. Secara umum dapat mengacu kepada sistem iman dan ibadat yang tertentu. Agama merupakan kesadaran akan adanya Allah yang benar dan merupakan tanggung jawab manusia kepada Dia. Hubungan antara teologi dan agama adalah hubungan akibat-akibat yang dihasilkan oleh sebabsebab yang sama, tetapi dalam kawasan yang berbeda. Dengan kata lain, dalam teologia manusia menata renungan-renungan tentang Tuhan dan alam semesta, dan dalam agama manusia mengungkapkan lewat sikap dan tindakan pengaruh dari semua perenungan tentang Tuhan. Teologi dalam konteks Indonesia modern perlu di pahami lebih jauh. Corak perjumpaan Kristen sesuai dengan hakikinya, adalah perjumpaan antara manusia dengan manusia. Allah ingin membangun hubungan dengan manusia dengan mengambil prakarsa turun kedunia melalui Kristus dan manusia harus menjawab. Namun permasalahannya adalah manusia yang berdosa tidak dimungkinkan mengenal Allah sejati dan manusia sejati, yaitu mengenal Kristus, dengan kata lain manusia yang berdosa mengalami keterasingan terhadap Allah, sesamanya dan diri sendiri, juga Kristus adalah pengantara mereka ${ }^{14}$ bahkan tanggapan mereka kepada-Nya dinodai dengan ketidaksetiaan.

Selalu ada unsur dosa di dalam iman manusia kepada Allah, mencari sesuatu kesetaraan dengan Allah dan jauh dilubuk hatinya mengontradiksikan

\footnotetext{
${ }^{13}$ John T. Mc Neill, ed., Calvin: Institutes of The Christian Religion (Philadelphia: The Westminster Press, 1960), 35-39; bdk G. W. Bromiley, ed. dan terj, Karl Barth, Church Dogmatics: A Selection with Introduction by Helmut Gollwitzer (Edinburgh: T\&T Clark, 1994), 87.

${ }^{14}$ Susabda, Teologi Modern I, 156.
} 
dirinya sendiri. ${ }^{15}$ Sebaliknya, kemungkinan manusia berdosa mengenal Kristus yang adalah Pengantara sejati, akan mengakibatkan mereka mungkin mengenal Allah dan diri mereka sendiri juga sesamanya manusia, yaitu pemulihan relasi dan pengharapan eskatologis atas permasalahan keterasingan manusia dengan Allah, dan sesamanya juga dirinya sendiri.

Pengharapan pemulihan relasi itu hanya dimungkinkan melalui pengantaraan Kristus bagi gereja-Nya oleh anugrah Allah sendiri dan yang menjadi efektif oleh pekerjaan Roh Kudus di dalam hati manusia berdosa. ${ }^{16}$ Dengan demikian, tidak dapat disangkali bahwa Kristus yang adalah Pengantara Sejati merupakan jalan keluar dari keterasingan manusia tersebut di atas yakni keterasingan dengan Allah, sesamanya dan diri sendiri. Sebab Dia adalah Allah sejati sekaligus manusia sejati. Sebagai Pengantara, Kristus tidak asing terhadap Allah, dan terhadap sesamanya manusia, juga terhadap diri-Nya sendiri yang adalah Allah sejati sekaligus manusia sejati. Kristus tidak asing terhadap Allah karena Dia adalah gambar Allah yang tidak kelihatan (Kol. 1:16; Yoh. 1:1-2, 18; 14:9) dan Putra Tunggal Allah sendiri yang dikasihi dan dikenan Allah (Mat. 3:17; 17:5). Kristus juga tidak asing terhadap manusia karena diciptakan di dalam Dia, melalui Dia dan untuk Dia (Kol. 1:16; Yoh. 1:3; 2:24-25; Rm. 8:29). Sebagai Pengantara, penyatuan sejati Kristus dengan Allah dan manusia sejati menjadi dasar yang kokoh bagi gereja dan upaya terus menerus mengenali pribadi Kristus secara lebih utuh sehingga terwujud penyatuan sejati mereka dengan Allah, sesamanya dan diri sendiri, juga tentunya dengan Kristus sendiri Pengantara mereka. ${ }^{17}$

\footnotetext{
${ }^{15}$ Douglas J. Elwood, Teologi Kristen Asia (Jakarta: BPK Gunung Mulia, 2006), 220.

${ }^{16}$ Wayne Grudem, Systematic Theology: An Introduction to Biblical Doktrine (Grand Rapids: Zondervan, 1994), 249, 634.

${ }^{17}$ Virgilia Fabella, "Kristologi dari Sudut Pandang Perempuan Asia," dalam Wajah Yesus di Asia, ed. R.S. Sugirtharajah (Jakarta: Gunung Mulia, 1996), 334.
}

Tak pelak lagi, Isu Inkarnasi Kristus sebagai pengantara yang sejati, sebab ia adalah Allah sejati dan manusia sejati, adalah begitu penting karenanya berbagai upaya gereja untuk mengenali pribadi Kristus secara lebih utuh perlu mendapat perhatian yang besar. Pengenalan akan pribadi Kristus secara utuh dapat dipandang dari segala dimensi keallahan maupun kemanusiaan-Nya, seperti bukan di cipta tetapi diperanakkkan di dalam kekekalan, Allah sejati dari Allah sejati, terlahir sebagai seorang Yahudi di awal abad masehi, dan berinkarnasi menjadi manusia. Jadi penulis akan menyoroti respon atau pergumulan masyarakat yang harus memahami Kristus sebagai Tuhan.

\section{Teologi dan Budaya}

Di telusuri, di Indonesia khususnya terjadi gejala kekristenan yang tidak terlembagakan ke dalam "kebudayaan" yang kristiani dan berdampingan secara berbeda dengan kebudayaan setempat. Ada jarak dan persepsi yang berbeda mengenai siapa Kristus. Apakah menjadi bagian dari masyarakat atau hanya sebuah doktrin saja. Tentu hal ini menjadi tantangan bagaimana implikasi teologis yang berpangkal sebenarnya pada "Kristus," mampu menjawab kebutuhan manusia ditengah himpitan hukum, keadilan, politik dan agama yang tidak lagi menjamin keamanan hidup. Secara universal ada hukum yang mengatur masyarakat, namun hal itu hanya menyangkut apa yang sudah ditetapkan oleh lembaga yang dilimpahi wewenang untuk merumuskan dasar stabilitas suatu bangsa. ${ }^{18}$ Sebaliknya keadilan sangat luas karena banyak hal yang kurang adil. Adil berarti adanya keseimbangan antara keteraturan dan anugerah (Yoh. 1:18). Kristus adalah satu-satunya hakim yang menjatuhi hukuman secara adil, justru karena menjaga keseimbangan tersebut. Perbedaan hukum dan keadilan sering berubah dengan pergolakan politik.

\footnotetext{
${ }^{18}$ W. Stanley Heath, Sains, Iman dan Teknologi
} (Yogyakarta: Yayasan ANDI, 1997), 193. 
Dari sisi budaya, secara kultural dalam masyarakat Indonesia, budaya adalah kebanggaan atau nilai diri suatu suku, sehingga sejalan dengan itu budaya memegang pengaruh yang sangat besar dalam kehidupan masyarakat Indonesia. "jantung kehidupan," yang mengontrol seluruh kehidupan manusia. Pencarian akan Allah di dapatkan melalui "kepercayaan," yang didapati atau dihidupkan dalam setiap tatanan kehidupan. Kristus belum "menyapa," hanya sebagian kecil dari suku-suku yang ada di Indonesia dan sebagian kecil belum memahami makna sebenarnya dari keselamatan.

\section{Teologi dan Modernisasi}

Mengkritisi bangsa Indonesia, para aparatur negara tidak lagi tunduk dibawah hukum yang sah, bertindak semena-mena terhadap keadilan bagi masyarakat, karena itu masyarakat bergejolak terhadap sistem pemerintahan yang "terselubung." Ketidakadilan mengacaukan seluruh rakyat dan sekaligus membawa kemerosotan moral. Di tengah-tengah situasi yang sulit di tengah bangsa ini, keadaan masyarakat yang sudah apatis dengan situasi bangsa dan di marginalkan membuat mereka mencari solusi.

Analisis sosial yang menjangkau kehidupan agama mengenai “Allah," karena itu teologi memandang situasi serius manusia dimana dari perspektif kekristenan orang percaya bahwa Allah dan Kristus telah hadir dalam kehidupan rakyat mencapai kemanusiaan yang penuh dengan memandang pengharapan dan penggenapan segala sesuatu tatkala Allah menjadi semua di dalam manusia (1 Kor. 15:28.)

Dari hal tersebut di atas pengaruh ilmu dan teknologi memperumit situasi masyarakat. Modernisasi cenderung menghancurkan rasa komunitas yang luas. Menjawab hal tersebut maka harus menetapkan iman dan interaksi timbal balik dengan masyarakat dengan memberikan teladan hidup yang memberi makna dan kesaksian Kristen. Otoritas dan penafsiran Alkitab adalah hal yang sangat vital. Oleh sebab itu langkah pendekatan yang harus dilakukan di tengah-tengah masyarakat.

\section{Teologi dan Filsafat}

Teologi dan filsafat secara praktis mempunyai tujuan-tujuan yang sama, namun demikian keduanya sangat berbeda dalam pendekatan dan cara mencapai tujuan itu. Teologi dan filsafat keduanya berusaha untuk memperoleh suatu pandangan dunia dan pandangan hidup yang komprehensif. Tetapi teologi bertolak dari keyakinan akan adanya Tuhan dan bahwa Dia merupakan sumber segala sesuatu kecuali dosa, maka filsafat bertolak dari suatu hal lain yang dianggap ada dan dari gagasan bahwa hal yang ada itu cukup untuk menjelaskan segala sesuatu yang ada. ${ }^{19}$ Sejarah Filsafat menggambarkan bagaimana para pemikir manusia berusaha menghindari tanggung jawab kepada Tuhan.

Jadi teologi bertumpu pada dasar obyektif yang kokoh sedangkan filsafat bertumpu pada dugaan-dugaan dan perkiraan-perkiraan filsafat itu sendiri. Sekalipun demikian filsafat memiliki nilai teologi. Namun filsafat tidak pernah mengantar orang pada Kristus. Paulus menulis, "Oleh karena dunia... tidak mengenal Allah oleh hikmat-Nya (1 Kor. 1: 21), dan 1 Korintus 2:6-8,

Sungguhpun demikian kami memberitakan hikmat di kalangan mereka yang matang, yaitu hikmat yang bukan dari dunia ini, dan yang bukan dari penguasa-penguasa dunia ini, yaitu penguasa-penguasa yang akan ditiadakan. Tetapi yang kami beritakan adalah hikmat Allah... tidak ada dari penguasa dunia ini yang mengenalnya, sebab kalau sekiranya mereka mengenal-Nya, mereka tidak menyalibkan Tuhan yang mulia.

Dalam masyarakat secara umum filsafat dianut sebagian besar orang mempertahankannya dengan kegigihan yang sama sebagaimana orang percaya menganut imannya. Jadi seseorang yang sudah berfilsafat tidak tertarik dengan Tuhan dan juga pernyataan tentang dirinya. Penolakan ini dilakukan karena dalam filsafat tidak ada pemeliharaan, dosa, keselamatan atau penggenapan akhir yang nyata. Berada dalam

${ }^{19}$ Jonar Situmorang, Filsafat dalam Terang Iman Kristen (Yogyakarta: Yayasan ANDI, 2004), 7. 
bayang-bayang karena semuanya dipimpin oleh ratio manusia.

Di tengah bangsa Indonesia yang "beragama," lapisan kehidupan masyarakat diracuni oleh ketidakpercayaan, apakah itu politik, perdagangan, pendidikan atau kemasyarakatan. Oleh karena itu sangat penting bagi orang Krsiten untuk senantiasa, "siap sedia dalam segala hal waktu untuk memberikan pertanggungan jawab kepada tiap-tiap orang yang meminta pertanggungan jawab... tentang pengharapan iman yang dimilikinya (1 Pet.3:15). Di tengah-tengah kemajuan bangsa ini yang sarat dengan ketidakpercayaan harus memiliki landasan yang kuat, sehingga tidak "diombang ambingkan oleh rupa-rupa angin pengajaran."

Oleh sebab itu orang percaya dalam Kristus memerlukan sebuah sistem berpikir yang teratur sehingga dapat mempertanggungjawabkan iman secara konsisiten. Alkitab menyediakan sebuah pandangan dunia yang konsisiten dan juga menyediakan jawaban jawaban terhadap masalah-masaah besar yang dihadapi oleh para filsuf sejak dulu dan membawa pemikiran yang benar bagi masayarakat atau individu yang terikat oleh arus pengetahuan filsafat.

\section{Teologi dan Etika}

Secara pribadi apapun yang dibangun dalam hidup, keluarga, komunitas, masyarakat dan seluruh aspek hidup berbicara tentang perilaku. Bagaimana dan mengapa timbul perilaku tertentu. Etika mempelajari sifat moral kelakuan. Etika bisa bersifat deskriptif yang mempelajari kelakuan manusia dari segi suatu tolak ukur tentang mana yang benar dan mana yang $\operatorname{salah}^{20}$, bisa pula praktis yang memberi landasan kepada etika deskriptif namun secara lebih khusus menekankan alasan-alasan untuk berusaha hidup menurut tolak ukur tersebut. Namun teologi memiliki wawasan yang lebih luas dari pada wawasan etika Kristen. Oleh sebab teologi mempelajari

${ }^{20}$ John M. Frame, Apologetika bagi Kemuliaan Allah, pen., R. Bg. Steve Hendra (Surabaya: Momentum, 2000), 71. ajaran tentang tritunggal ilahi, penciptaan, pemeliharaan, kejatuhan manusia, penjelmaan, penebusan dan eskatologi. Semua pokok ini tidak termasuk dalam wawasan etika.

Menarik bahwa dalam kaitannya dengan perilaku dan tujuan hidup kembali lagi bersumber kebenarannya kepada Alkitab dan Kristus adalah sentral atau jawaban dari kebutuhan etika sekalipun. Ada jawaban dan aturan bagaimana meresponi dan menempatkan diri ditengah-tengan angkatan yang berbalik dari pada Kristus, memiliki kehidupan yang bebas dan hidup dalam pengaruh pemahaman dunia yang menarik mereka kepada kabutaan hidup dan kehancuran hidup.

Untuk mampu berada di tengah kultur budaya yang besar ini maka harus menjaga perilaku dan karakter sehingga dimanapun dan kapan pun bisa menjadi terang yang mewarnai seluruh kehidupan di tengah bangsa ini. Matius 5:16, Firman Tuhan berkata, "Demikianlah hendaknya terangmu bercahaya di depan orang, supaya mereka melihat perbuatanmu yang baik dan memuliakan Bapamu yang di sorga."

\section{TEOLOGI SEBAGAI KRITIK}

Kritik ini adalah langkah persiapan ke arah refleksi teologis. Perjumpaan secara pribadi dengan Kristus yang adalah manusia sejati dan Allah sejati menentukan cara kita bisa menjadi peka terhadap misteri eksistensi manusia terhadap Allah. Di era postmodern ini, pseudo-church semakin muda teridentifikasi, dan bisa di temukan di banyak kota di Indonesia. Spirit zaman postmodernisme ${ }^{21}$ yang di tandai dengan, "cara berpikir baru," tentang kebenaran sehingga menghasilkan "cara hidup baru," yaitu cara hidup pasar. ${ }^{22}$

${ }^{21}$ Postmodernisme adalah perubahan cara berpikir, yaitu meninggalkan cara berpikir dan pola cara hidup modern mencari cara berpikir dan cara hidup tanda bentuk.

${ }^{22}$ Linda Hutcheon, Politik Postmodernisme (Yogyakarta: Penerbit Jendela, 2004), 1. 
Cara berpikir dalam era modern ini, sangat kuat dipengaruhi oleh cara berpikir masyarakat yang hedonistik, konsumtif, instanistik, kompromistis, dan pragmatik. Gereja-gereja tertentu menjadi sangat dinamis, karena anggota-anggota jemaatnya "mengkonsumsi apa saja," menjadi kaya jasmani dan rohani dalam waktu yang singkat; sekalipun rela berkompromi dengan zaman, gereja berjuang menjadi berguna bagi masyarakat karena takut kehilangan anggotanya. Jadi gereja berusaha memenuhi kebutuhan pola-pola ibadah yang sarat hiburan. Gereja pun berubah dan sedang bergeser sehingga gereja kehilangan pegangan (Theological Traditions), identitas (Theological Meanings) dan kehilangan pengaruh (Theological Roles).

Oleh sebab itu teologi dapat mempengaruhi kehidupan berdasarkan karya Kristus. ${ }^{23}$ Harus dipahami bahwa gereja tidak ditentukan oleh penguasa politik-ekonomi, oleh undang-undang manapun melainkan jaminan Kristus yang dibangun atas kehendak-Nya (Mat.16:18.) Gereja itu unik dan uviersal, kudus, esa, dan apostolik. Terlihat dengan jelas posisi gereja. Menurut G. C. Berkowner,aspek gereja dalam studi dogmatikanya tentang hakekat gereja menjelaskan empat aspek dari gereja sebagai berikut:

\section{Kesatuan-Unity (Ef. 4:1-6)}

Sekalipun komunitas orang percaya terdiri dari berbagai etnis, budaya di Indonesia ini tetapi pada dasarnya menjadi satu kesatuan komunitas, yaitu umat Allah. Tetapi sekalipun secara organisatoris terdiri dari berbagai denominasi, tetapi secara teologis dihadapan Allah gereja merupakan satu tubuh Kristus, yaitu satu kesatuan umat Allah.

\section{Kekudusan-Holiness (1 Pet. 1:15-16)}

Sesuai dengan panggilan Allah dalam karya penebusan Kristus sebagai Pengantara, gereja dan setiap pribadi di dalamnya harus memiliki karak-

${ }^{23}$ Charles C. Ryrie, Teologi Dasar 2: Panduan Populer untuk Memahami Kebenaran Alkitab (Yogyakarta: Andi Offset, 2010), 10. teristik kekudusan. Kekudusan gereja buka berdasarkan kekudusan legalisme, juga bukan berdasarkan pengisolisasian diri atau cara hidup yang ekskusif, melainkan berdasarkan hidup gereja yang tidak tercemar oleh dosa dan kebobrokan peradaban bangsa di mana gereja di tengah-tengahnya. Gereja harus memberi dampak memberitakan misi Allah. ${ }^{24}$ Gereja dipanggil untuk menjadi umat yang kudus dan berfungsi menjadi garam dan terang.

\section{Universal-Catholicity (Am)}

Sebagai umat Allah gereja tidak dibatasi oleh ruang dan waktu. Maksudnya ia tidak dipisahkan oleh tempat, letak geografis, perbedaan masa dan berlangsungnya waktu, bahkan ia tidak dipisahkan dari budaya, suku dan bangsa. Karena semua manusia yang pernah hidup sebelumnya dan akan datang yang percaya di dalam Yesus Kristus merupakan umat Allah, oleh sebab itu semua umat Allah atau gereja bersifat universal.

\section{Apostolik-Apostolicity (Ef. 2:20)}

Gereja berdiri diatas pengajaran para rasul, yang bersumber dari Yesus Kristus dan dari Perjanjian Lama, pengakuan para rasul terhadap Perjanjian Lama berdasarkan pimpinan Roh Kudus dan otoritas dari Allah. Pengajaran tersebut tertuang dalam Alkitab. Jelaslah bahwa gereja berdiri di atas pengajaran Alkitab. Rahasia Allah berbicara tentang "Injil," bagaimana bisa sampai dengan benar kepda setiap orang dengan menyakini bahwa Kristus benar-benar Allah sejati yang berinkarnasi dengan tujuan karya penyelamatan. ${ }^{25}$ Tidak ada jalan lagi, metode, strategi selain mempercayai karya penyelamatan. Gereja-gereja jangan berdiam diri dan sibuk dengan pengalaman kedalam, tidak menghadapi isu-isu yang ada yang berhubungan dengan Kristologi bah-

${ }^{24}$ R. T. France, Yesus Sang Radikal: Potret Manusia yang Disalibkan (Malang: Gunung mulia, 1996), 43.

${ }^{25}$ Erwin W. Lutzer, Teologi Kontemporer: Berbeda Namun Satu Tubuh (Malang: Gandum Mas, 2005), 48. 
wa pengenalan akan Kristus melalui kasih-Nya yang "membumi," menjangkau orang yang terpinggirkan, remuk hatinya, dibuang, dihina masyarakat dan melepaskan dari pengetahuan manusia yang terbatas dan dari kematian yang kekal. Hanya dengan Pengenalan mutlak kepada Kristus (Kol. 2:2; Fil. 3:8-10). Jadi tidak paradoks dengan Kristus yang adalah Juruselamat.

\section{KESIMPULAN}

Penulisan makalah ini mengambil tiga kesimpulan, sebagai berikut:

Pertama, isu Kristologi senantiasa dekat dengan kehidupan masyarakat. Alkitab dengan jelas memaparkan karya Kristus yang adalah Allah sejati dan manusia sejati yang rela turun ke dunia sebagai Pengantara antara Allah dan manusia agar memperoleh anugerah. Pemahaman kristologis yang akurat dan benar sesuai Alkitab memang menjadi dasar yang penting guna membangun teologi kristiani yang korektif. Oleh karena itu penting sekali menanggapi bahwa Kristus sebagai Pengantara adalah "jalan," satu-satunya yang akan menjawab kehidupan setiap orang yang percaya.

Kedua, doktrin Kristologi atau Kristus dapat dilihat sebagai inti dari tema teologi dan kunci yang paling memadai karena itu misi Allah bagi gereja adalah menghidupi nilai-nilai kerajaan Allah, mewakili Allah mengelola kehidupan dimuka bumi bagi ke-

\section{DAFTAR RUJUKAN}

Borchert, G. L. "Docetism." Dalam Evangelical Dictionary of Theology. Ed. Walter A. Elwell. Grand Rapids: Baker Book House, 1984.

Browning, W.R.F. "Teologi.” dalam Kamus Alkitab: Panduan dasar ke dalam Kitab-kitab, Tema, tempat, Tokoh dan Istilah Alkitabiah. Penyunting Liem Khiem Yang dan Bambang Subandrijo. Jakarta: Gunung Mulia, 2007.

Elwood, Douglas J. Teologi Kristen Asia. Jakarta: BPK Gunung Mulia, 2006. muliaan Allah sebagai alat penyataan anugerah-Nya bagi segala suku ditengah-tengah bangsa yang besar ini, dimana 85 persen mayoritas non Kristen. Jadi penting penyataan Kristus bagi Indonesia.

Ketiga, nilai-nilai dunia menawarkan materialisme dan individualisme yang hanya menekankan fenomena dunia fana saja dan mengabaikan realitas rohani. Jarak antara gereja dan masyarakat semakin jauh, bahkan isi gereja atau jemaat tercemari oleh sistem dunia. Paulus mengajarkan bagaimana menjadi saksi Kristus yang mendatangkan rahmat Allah di tengah-tengah bangsa Indonesia ini yang telah kehilangan identitasnya. Perkataan Tuhan Yesus, "Dunia akan mengenal kalian adalah murid-murid-Ku, bila kalian saling mencintai satu dengan yang lain." Ditambah oleh penghayatan iman Rasul Yohanes akan sabda Kristus yang pernah dituliskan dalam suratnya, inilah tandanya anak-anak Allah dan anak-anak Iblis: setiap orang yang tidak berbuat kebenaran, tidak berasal dari Allah. Sementara barangsiapa tidak mengasihi saudaranya, tidak mengasihi, ia tetap di dalam maut. Anak-anak-Ku marilah saling mengasihi bukan dengan perkataan atau dengan lidah, tetapi dengan perbuatan dan dalam kebenaran. Jadi berteologi dalam konteks Indonesia adalah panggilan hidup yang berorientasi kerajaan Allah. Membangun bangsa dengan pengajaran yang benar karena Kristus sebagai jawaban bagi bangsa Indonesia.

End, Th. Van den. Enam Belas Dokumen dasar Calvinisme. Jakarta: Gunung Mulia, 2004.

Erickson, Millard J. Christian Theology Vol. 2. Grand Rapids: Baker Book House, 1984.

Erickson, Millard J. Teologi Kristen. Volume 3. Malang: Gandum Mas, 2004.

Evans, Toni. Teologi Allah. Malang: Gandum Mas, 1999.

Fabella,Virgilia. "Kristologi dari Sudut Pandang Perempuan Asia." Dalam Wajah Yesus di Asia. 
Ed. R.S. Sugirtharajah. Jakarta: Gunung Mulia, 1996.

Frame, John M. Apologetika bagi Kemuliaan Allah. Penerjemah R. Steve Hendra. Surabaya: Momentum, 2000.

France, R. T. Yesus Sang Radikal: Potret Manusia yang Disalibkan. Malang: Gunung Mulia, 1996.

Grudem, Wayne. Systematic Theology: An Introduction to Biblical Doktrine. Grand Rapids: Zondervan, 1994.

Heath, W. Stanley. Sains, Iman dan Teknologi. Yogyakarta: Yayasan ANDI, 1997.

Hutcheon, Linda. Politik Postmodernisme. Yogyakarta: Penerbit Jendela, 2004.

Lane, Toni. Runtut Pijar.Terjemahan Conny Item Corputy. Jakarta: Gunung Mulia, 1993. J. F. Jhonson "Athanasius." Dalam Evangelical Dictionary of Theologia. Ed. Walter A. Elwell Grand rapids: Baker Book House, 1984.
Lutzer, Erwin W. Teologi Kontemporer: Berbeda Namun Satu Tubuh. Malang: Gandum Mas, 2005.

Neill, John T. Mc. EdisiCalvin: Institutes of The Christian Religion. Philadelphia: The Westminster Press, 1960; bdk G. W. Bromiley. Ed. dan Terj.Karl Barth, Church Dogmatics: A Selection with Introduction by Helmut Gollwitzer.Edinburgh: T\&T Clark, 1994.

Ryrie, Charles C. Teologi Dasar 2: Panduan Populer untuk Memahami Kebenaran Alkitab. Yogyakarta: Andi Offset, 2010.

Situmorang, Jonar. Filsafat dalam Terang Iman Kristen. Yogyakarta: Yayasan ANDI, 2004.

Susabda, Yakub S. Teologi Modern I.Jakarta: LRII, 1990.

Thiessen, Henry C. Teologi Sistematika. Edisi revisi Vernon D. Doerksen. Malang: Gandum Mas, 2000.

Walton, Robert C. Chronological and Background Charts of Church History.Grand Rapids: Zondervan, 1986. 